\title{
Liposome-based Intranasal Delivery of Lipopeptide Vaccine Candidates Against Group A Streptococcus
}

Khairunnisa Abdul Ghaffar ${ }^{1}$, Nirmal Marasini ${ }^{1}$, Ashwini Kumar Giddam ${ }^{1}$, Michael

Batzloff $^{2}$, Michael Good ${ }^{2}$, Mariusz Skwarczynski ${ }^{1}$, Istvan Toth ${ }^{1,3,4^{*}}$

${ }^{1}$ The University of Queensland, School of Chemistry and Molecular Biosciences, Brisbane, QLD 4072, Australia.

${ }^{2}$ Institute for Glycomics, Griffith University, Gold Coast 4215, Australia

${ }^{3}$ The University of Queensland, School of Pharmacy, Brisbane, QLD 4072, Australia.

${ }^{4}$ The University of Queensland, Institute for Molecular Biosciences, St Lucia, QLD 4072, Australia

*Corresponding author

Professor Istvan Toth PhD DSc FRACIFQA

Chair in Biological Chemistry

School of Chemistry \& Molecular Biosciences

Professor of Pharmacy

School of Pharmacy

Editor-in-Chief, Current Drug Delivery

Editor-in-Chief, Drug Delivery Letters

University of Queensland

Chemistry Blg \#68

StLucia, Qld 4072

Tel. (617) 33469892

Fax (617) 33654273

E-mail: i.toth@uq.edu.au 


\begin{abstract}
:
Group A Streptococcus (GAS), an exclusively human pathogen, causes a wide range of diseases ranging from trivial to life threatening. Treatment of infection is often ineffective following entry of bacteria into the bloodstream. To date, there is no vaccine available against GAS. In this study, cationic liposomes encapsulating lipopeptide-based vaccine candidates against GAS have been employed for intranasal vaccine delivery. Cationic liposomes were prepared with dimethyldioctadecylammonium bromide (DDAB) using the film hydration method. Female Swiss mice were immunized intranasally with the liposomes. In contrast to unmodified peptides, lipopeptides entrapped by liposomes induced both mucosal and systemic immunity, IgA and $\operatorname{IgG}$ (IgG1 and IgG2a) production in mice, respectively. High levels of antibody (IgA and $\mathrm{IgG}$ ) titres were detected even five months post immunization. Thus, the combination of lipopeptides and liposomes generates a very promising delivery system for intranasal vaccines.
\end{abstract}

Keywords: Cationic liposomes, Group A Streptococcus, intranasal immunization, peptide vaccine. 


\section{Introduction}

Group A Streptococcus (GAS), also known as Streptococcus pyogenes, is a gram positive bacterium, which infects more than 600 million people each year [1] contributing to millions of dollars in healthcare expenditure. Clinical manifestations of GAS infections such as pharyngitis or impetigo, are typically self-limiting [2]. However, if left untreated, the disease can progress to an invasive state which may lead to life threatening diseases such as necrotizing fasciitis and streptococcal toxic shock syndrome (STSS) [3,4]. Carapetis et al. estimated the number of invasive GAS (iGAS) disease cases exceeds half a million annually [1]. Approximately $20 \%$ of patients with iGAS disease die within a week of infection $[5,6]$. The mortality rate increases by $25 \%$ if the patient develops STSS. Although these diseases are of special concern, GAS mortality is mainly associated with rheumatic heart diseases (RHD) and rheumatic fever (RF). It has been estimated that 19 million people suffer from RHD and the annual death toll approximates 470000 worldwide [7].

The main route of GAS infection is through direct contact of bacteria with the mucosal membrane $[6,8]$. Courtney et al. demonstrated that the binding of GAS to substratum involves the $M$ protein [9]. The $M$ protein is a major virulence factor of GAS, which is expressed by all pathogenic strains. Apart from functioning as an adhesin, the M protein has an antiphagocytic property to increase bacterial survival in the host [10]. This alpha-helical coiled dimer protein comprises four distinct repeat regions (A to D) that have varying percentages of conservation $[9,11]$. M protein is hypervariable at the $\mathrm{N}$-terminal where there are more than 250 known emm-serotypes whereas its C-repeat region is highly conserved [11].

Protected individuals' express IgG antibodies, which are reactive to the M protein, making this protein the perfect target for vaccine development. However, the full 
length M protein contains sequences similar to human cardiac tissues; therefore, it is not feasible to utilize the whole protein as a vaccine antigen [12]. Massell et al. showed that some patients developed rheumatic fever following vaccination with type 3 streptococcal M protein [13]. Hence, peptides derived from $M$ protein rather than whole protein have been used as a safe alternative for vaccine development against GAS. Hayman et al. described minimal antigenic epitopes, J8 and J14 from the M protein [14]. These epitopes have formed the basis of a number of vaccine studies to induce systemic and mucosal immunity [15].

M protein epitope-based GAS vaccine candidates were reported to induce strong systemic humoral immunity (i.e. production of $\operatorname{IgG}$ ) [16,17]. However, GAS typically colonizes the epithelia of the osopharynx; thus, the induction of mucosal immunity [production of secretory $\operatorname{IgA}(\operatorname{sg} \mathrm{A})]$ is required as a primary barrier, protecting mucosal surfaces from colonization by the bacteria [18].

Recently, we have designed and synthesised a library of vaccine candidates bearing the J14 peptide sequence (KQAEDKVKASREAKKQVEKALEQLEDKVK), a conserved B-cell epitope derived from the $M$ protein of GAS and P25 (KLIPNASLIENCTKAEL), a universal T-helper epitope. The epitopes were incorporated into the lipid core peptide (LCP), a self-adjuvanting carrier system which combines peptide epitopes, branching moiety (e.g. lysine) and lipoamino acid into one molecule. LCP has been extensively used as a peptide-based vaccine delivery system and showed high efficacy to stimulate immune responses against hookworm $[19,20]$, malaria [21], Schistosoma [20,22] and cancer [23]. While the majority of reported LCP conjugates induced strong systemic responses, only lipopeptide $\mathbf{1}$ (Figure 1) was able to induce mucosal immunity [24]. This compound also stimulated systemic immune responses in mice model $[24,25,26]$ and was able to activate toll 
like receptor 2 [27]. In order to further improve the efficacy of this vaccine candidate, we incorporated $\mathbf{1}$, and newly designed lipopeptides bearing the same epitopes, into cationic liposomes (Figure 1b). These liposomes stimulated high levels of IgG and IgA titres even five months following final immunization.

\section{Experimental Section}

\subsection{Materials}

All chemical materials used in this study were analytical grade unless otherwise stated. Protected L-amino acids were obtained from Novabiochem (Läufelfingen, Switzerland) or Reanal (Budapest, Hungary). Rink amide MBHA resin, dichloromethane (DCM), methanol, chloroform $N, N$-diisopropylethylamine (DIPEA), piperidine, HPLC grade acetonitrile and trifluoroacetic acid (TFA) were purchased from Merck (Hohenbrunn, Germany). 1-[Bis(dimethylamino)methylene]-1H-1,2,3triazolo[4,5-b]pyridinium 3-oxid hexafluorophosphate (HATU) was purchased from Mimotopes (Melbourne, Australia). Dipalmitoylphosphatidylcholine (DPPC), cholesterol and dimethyldioctadecylammonium bromide (DDAB) were purchased from Avanti (Alabaster, AL). Avanti Mini Extruder, PC membranes and filter supports were purchased from Avanti (Alabaster, AL). Iscove's Modified Dulbecco's

medium (IMDM) glutamax, fetal bovine serum (FBS), Penicillin-Streptomycin, Dulbecco's Modified Eagle Medium (DMEM) and IC Fixation buffer were purchased from Life Technologies. Antibodies, CD11c-A660 and F4/80-APC-Cy7 were purchased from BioLegend, USA while secondary antibodies (IgG, IgG1, IgG2a and IgA) were purchased from Sigma Aldrich, Australia. Lipoamino acid (2-(R/S)-[(tert- 
butoxycarbonyl) amino]-hexadecanoic acid) was synthesised as previously reported [28].

Preparative reversed phase high performance liquid chromatography (RP-HPLC) was performed on Shimadzu (Kyoto, Japan) instrumentation (either LC-20AT, SIL-10A, CBM-20A, SPD-20AV, FRC-10A or LC- 20AP x 2, CBM-20A, SPD-20A, FRC10A) in linear gradient mode using a 10-20 $\mathrm{mL} / \mathrm{min}$ flow rate, with detection at 230 nm. Analytical RP-HPLC was performed using an Agilent (Agilent 1100 series) instrument with a $1 \mathrm{~mL} / \mathrm{min}$ flow rate and detection at $214 \mathrm{~nm}$.

\subsection{Methods}

\subsubsection{Peptide Synthesis}

\subsubsection{J14 peptide, (KQAEDKVKASREAKKQVEKALEQLEDKVK)}

J14 was synthesised on a $0.2 \mathrm{mmol}$ scale via the 9-fluorenylmethyloxycarbonyl (Fmoc) solid phase peptide synthesis (SPPS). The rink amide 4methylbenzhydrylamine (MBHA) resin was pre-swelled with dimethylformamide (DMF) for a minimum of two hours' prior synthesis. Deprotection of Fmoc was performed twice, with $20 \%$ piperidine/DMF for 1 × 5 min and 1 x $15 \mathrm{~min}$. Each amino acid was coupled twice, $2 \times 1$ hours to increase coupling efficiency. Amino acid (4.0 equivalents) was activated with $0.5 \mathrm{M}$ (1-[bis(dimethylamino)methylene]1H-1,2,3-triazolo[4,5-b]pyridinium 3-oxid hexafluorophosphate) (HATU)/DMF (4.0 equivalents) and 4.2 equivalents of $N, N$-diisopropylethylamine (DIPEA) as the neutralising base. This process was repeated until the desired sequence was attained. Following synthesis, the peptide-resin was washed thrice with DMF, dichloromethane 
(DCM) and methanol before overnight drying in a desiccator. The peptide was cleaved from the resin using a cocktail of trifluoroacetic acid (TFA):triisopropylsilane (TIS):water (95:2.5:2.5). TFA was removed under reduced pressure and peptide was precipitated with cold diethyl ether. The peptide precipitate was subsequently dissolved in acetonitrile/water (50:50) prior to lyophilization. J14 was purified using Shimadzu preparative RP-HPLC on the C18 Vydac column with a solvent gradient of 0-50\%, $10 \mathrm{~mL} / \mathrm{min}$ solvent B (90\% acetonitrile, 10\% Milli Q water, $0.1 \% \mathrm{TFA}$ ). Analytical HPLC analysis was performed using the C18 column (Grace): $t_{R}=18.7$ min, purity > 98\%. ESI-MS: $[\mathrm{M}+2 \mathrm{H}]^{2+} \mathrm{m} / \mathrm{z} 1699.2$ (calculated 1698.9); $[\mathrm{M}+3 \mathrm{H}]^{3+}$ $\mathrm{m} / \mathrm{z} 1133.4$ (calculated 1132.7); $[\mathrm{M}+4 \mathrm{H}]^{4+} \mathrm{m} / \mathrm{z} 850.1$ (calculated 849.8); $[\mathrm{M}+5 \mathrm{H}]^{5+}$ $\mathrm{m} / \mathrm{z} 680.2$ (calculated 680.1); $[\mathrm{M}+6 \mathrm{H}]{ }^{6+} \mathrm{m} / \mathrm{z} 567.3$ (calculated 566.9). M.W.= 3395.9

\subsubsection{P25 peptide, (KLIPNASLIENCTKAEL)}

Peptide P25, a T cell helper, was synthesised on a 0.2 mmol scale using the standard Fmoc SPPS technique on a rink amide MBHA resin. The synthesis and purification of P25 was similar to that of J14. Analytical HPLC analysis was performed on a C18 column $($ Grace $): t_{R}=26.5 \mathrm{~min}$, purity $>98 \%$. ESI-MS: $[\mathrm{M}+\mathrm{H}]^{+} \mathrm{m} / \mathrm{z} 1898.7$ (calculated 1898.2); $[\mathrm{M}+2 \mathrm{H}]^{2+} \mathrm{m} / \mathrm{z} 950.4$ (calculated 950.1). M.W.= 1898.2

\subsubsection{Lipopeptide synthesis}

Lipopeptides 1-5 were synthesised using tert-butyloxycarbonyl (Boc) SPPS. The peptides were synthesised on a $0.2 \mathrm{mmol}$ scale using MBHA resin. Coupling reagents used to activate and couple the amino acids were the same as those in the Fmoc synthesis. Microwave-assisted Boc SPPS was carried out by using a SPS mode CEM Discovery reactor. Each amino acid was coupled twice, 1 x 5 min and $1 \times 10$ min at 
$70{ }^{\circ} \mathrm{C}$ with DMF washes in between. Deprotection of the Boc group was achieved using TFA, 2 x 1 min with stirring at room temperature. Fmoc side-chain protected lysine was used for branching in order to attach both epitopes, J14 and P25. The Fmoc group was removed using $20 \%$ piperidine. Hydrofluoric acid (HF) was used to cleave the peptides from the resin. $\mathrm{HF}$ cleavage $\left(10 \mathrm{~mL} \mathrm{HF} / \mathrm{g}\right.$ resin) was performed at $-8^{\circ} \mathrm{C}$ in the presence of 5\% (v/v) $p$-cresol and 5\% (v/v) p-thiocresol.

\subsubsection{Lipopeptide 1}

Lipopeptide 1 was purified using preparative Shimadzu RP-HPLC on the C4 Vydac column with a solvent gradient of $55-80 \%$ solvent B. Analytical HPLC analysis was performed using Agilent instrument $(\mathrm{C} 4$ column $): t_{R}=27.9 \mathrm{~min}$, purity $>95 \%$. ESIMS: $[\mathrm{M}+4 \mathrm{H}]^{4+} \mathrm{m} / \mathrm{z} 1522.5$ (calculated 1522.5); $[\mathrm{M}+5 \mathrm{H}]^{5+} \mathrm{m} / \mathrm{z} 1218.4$ (calculated 1218.2); $[\mathrm{M}+6 \mathrm{H}]^{6+} \mathrm{m} / \mathrm{z} 1015.3$ (calculated 1015.3); $[\mathrm{M}+7 \mathrm{H}]^{7+} 870.5$ (calculated 870.4); $[\mathrm{M}+8 \mathrm{H}]^{8+} 762.0$ (calculated 761.7). M.W.= 6086.3

\subsubsection{Lipopeptide 2}

Lipopeptide 2 was purified using preparative Shimadzu RP-HPLC on the C4 Vydac column with a solvent gradient of $53-63 \%$ B. Analytical HPLC analysis was performed using Agilent instrument (C4 column): $t_{R}=22.7 \mathrm{~min}$, purity $>95 \%$. ESIMS: $[\mathrm{M}+2 \mathrm{H}]^{2+} \mathrm{m} / \mathrm{z} 1976.4$ (calculated 1976.8); $[\mathrm{M}+3 \mathrm{H}]^{3+} \mathrm{m} / \mathrm{z} 1318.0$ (calculated 1318.2); $[\mathrm{M}+4 \mathrm{H}]^{4+} \mathrm{m} / \mathrm{z} 988.7$ (calculated 988.9); $[\mathrm{M}+5 \mathrm{H}]^{5+} \mathrm{m} / \mathrm{z} 791.5$ (calculated 791.3); $[\mathrm{M}+6 \mathrm{H}]^{6+} \mathrm{m} / \mathrm{z} 659.8$ (calculated 659.6). M.W.=3951.6

\subsubsection{Lipopeptide 3}

Lipopeptide 3 was purified using preparative Shimadzu RP-HPLC on the C4 Vydac column with a solvent gradient of 53-63\% solvent B. Analytical HPLC analysis was 
performed using Agilent instrument (C4 column): $t_{R}=22.7$ min, purity $>95 \%$. ESIMS: $[\mathrm{M}+\mathrm{H}]^{+} \mathrm{m} / \mathrm{z} 2454.4$ (calculated 2454.0); $[\mathrm{M}+2 \mathrm{H}]^{2+} \mathrm{m} / \mathrm{z} 1228.7$ (calculated 1228.0); $[\mathrm{M}+3 \mathrm{H}]^{3+} \mathrm{m} / \mathrm{z} 819.1$ (calculated 818.1). M.W.= 2454.0

\subsubsection{Lipopeptide 4}

Lipopeptide 4 was purified using preparative RP-HPLC on the C4 Vydac column with a solvent gradient of $50-70 \%$ solvent B. Analytical HPLC analysis was performed using Agilent instrument (C4 column): $t_{R}=27.6 \mathrm{~min}$, purity $>95 \%$. ESIMS: $[\mathrm{M}+2 \mathrm{H}]^{2+} \mathrm{m} / \mathrm{z} 2102.6$ (calculated 2103.5); $[\mathrm{M}+3 \mathrm{H}]^{3+} \mathrm{m} / \mathrm{z} 1402.9$ (calculated 1402.7); $[\mathrm{M}+4 \mathrm{H}]^{4+} \mathrm{m} / \mathrm{z} 1052.7$ (calculated 1052.2); $[\mathrm{M}+5 \mathrm{H}]^{5+} \mathrm{m} / \mathrm{z} 842.2$ (calculated 842.0); $[\mathrm{M}+6 \mathrm{H}]^{6+} 702.3$ (calculated 701.8). M.W.=4205.1

\subsubsection{Lipopeptide 5}

Lipopeptide 5 was purified using preparative RP-HPLC on the C4 Vydac column with a solvent gradient of $55-80 \%$ solvent B. Analytical HPLC analysis was performed using Agilent instrument (C4 column): $t_{R}=30.7 \mathrm{~min}$, purity $>95 \%$. ESIMS: $[\mathrm{M}+\mathrm{H}]^{+} \mathrm{m} / \mathrm{z} 2707.6$ (calculated 2707.4); $[\mathrm{M}+2 \mathrm{H}]^{2+} \mathrm{m} / \mathrm{z} \quad 1354.5$ (calculated 1354.7); $[\mathrm{M}+3 \mathrm{H}]^{3+} \mathrm{m} / \mathrm{z} 903.7$ (calculated 903.5). M.W.=2707.4

\subsubsection{Formulation of liposome vaccine constructs}

All lipids (DPPC, DDAB and cholesterol) were dissolved in chloroform prior to formulation; DPPC:DDAB:Chol in a molar ratio of 5:2:1. Chloroform was slowly evaporated under slightly reduced pressure with the help of rotatory evaporator. Residual chloroform was removed under vacuum overnight. Antigen was dissolved in sterile Milli Q water prior to hydration of the lipid film. Liposomes were formulated 
using lipid hydration method [29] at $56{ }^{\circ} \mathrm{C}$ prior to extrusion with a $0.1 \mu \mathrm{m}$ PC membrane.

\subsubsection{Liposomal Characterization}

Liposomal size was measured by photon correlation spectroscopy using a Zetasizer $3000^{\mathrm{TM}}$ (Malvern Instruments, Malvern, UK). To calculate loading efficacy, a predetermined amount of antigen was encapsulated into liposomes, which were then pelleted by ultracentrifugation (Beckman TLA100.2 rotor at $100000 \mathrm{rpm} \mathrm{X} 1 \mathrm{hr}$ ). The supernatant was removed prior lysing with methanol. The amount of antigen was measured against a known standard curve using an ultraviolet-visible spectroscopy (UV-Vis) at wavelength $214 \mathrm{~nm}$.

\subsubsection{Transmission electron microscopy}

Liposomal samples were prepared as mentioned above. Following extrusion, samples were diluted 10X before fixing to carbon-coated 200 mesh grid. Excess liposomal formulation was remoyed after three minutes. Pictures were taken using JEM-1010 transmission electron microscope (JOEL Ltd., Japan).

\subsubsection{Cell uptake studies}

Samples were processed under sterile conditions. Murine spleens kept in DMEM buffer were transferred onto a $70 \mu \mathrm{m}$ strainer and mashed. The cell strainer was washed with complete IMDM buffer (IMDM Glutamax medium supplemented with 10\% FBS, $50 \mu \mathrm{M}$ 2-mercaptoethanol, $100 \mathrm{U} / \mathrm{mL}$ penicillin, and $100 \mu \mathrm{g} / \mathrm{mL}$ streptomycin) and centrifuged at $400 \mathrm{~g}$ for 10 minutes. The supernatant was discarded and the pellet resuspended in $1 \mathrm{~mL}$ of erylysis buffer and incubated for seven minutes. Cells were stained with tryphan blue and counted using the haemocytometer. Cells 
were seeded at a density of $1 \times 10^{6}$ cells/well and incubated for two hours at $37^{\circ} \mathrm{C}$ in a $5 \% \mathrm{CO}_{2}$ incubator. Liposomes stained with Dil were added to each well and incubated overnight at $37{ }^{\circ} \mathrm{C}$ in a $5 \% \mathrm{CO}_{2}$ incubator. Cells were scraped and centrifuged at $400 \mathrm{~g}$ for 10 minutes. The supernatant was discarded. Fc-blocker (1:1000) was added into FACS buffer $(0.5 \%$ bovine serum albumin, $0.02 \% \mathrm{mg}$ sodium azide, in PBS) before pipetting $40 \mu \mathrm{L}$ into each well and incubated at $4{ }^{\circ} \mathrm{C}$ for 20 minutes before centrifugation at $400 \mathrm{~g}$ for five minutes. Pellets were resuspended in $50 \mu \mathrm{L}$ antibody cocktail buffer (CD 11c-A660 and F4/80-APC-Cy7 antibodies) and incubated for 30 minutes at $4{ }^{\circ} \mathrm{C}$. FACS buffer $(150 \mu \mathrm{L})$ was added to each well prior centrifugation at $400 \mathrm{~g}$, for five minutes. Cells were then washed thrice with increasing amounts of FACS buffer $(100 \mu \mathrm{L}, 150 \mu \mathrm{L}$ and $200 \mu \mathrm{L})$. Fixation buffer (50 $\mu \mathrm{L}$ ) was added into each well and incubated for 20 minutes. This was then topped up with $150 \mu \mathrm{L}$ FACS buffer and centrifuged at $400 \mathrm{~g}$, for five minutes. The supernatant was discarded and $200 \mu \mathrm{L}$ FACS buffer was added. The cells were kept in dark conditions at $4{ }^{\circ} \mathrm{C}$ till analysis using a BD LSRII flow cytometer was performed.

\subsubsection{Immunological assessment}

All animal protocols were approved by the Institute's ethics committee (Griffifth University Research Ethics Review Board for Animal-Based Work-GU ref no. GLY01-15-AEC) in accordance with National Health and Medical Research Council (NHMRC) of Australia. Female outbred ARC-Swiss mice (The Animal Resource Centre, Perth, Western Australia) were intranasally immunized on day 0 with $20 \mu \mathrm{L}$ (10 $\mu \mathrm{L} /$ nare) of liposomal formulation, which contained $60 \mu \mathrm{g}$ of antigen, followed by two booster doses on day 21 and day 42 (Figure 2). Mice receiving positive controls were intranasally immunized with $60 \mu \mathrm{g}$ of peptides mixed with $10 \mu \mathrm{g}$ cholera toxin $\mathrm{B}$ 
subunit (CTB) dissolved in $30 \mu \mathrm{L}$ of phosphate-buffered saline (PBS). Negative control mice were immunized with $30 \mu \mathrm{L}(15 \mu \mathrm{L} /$ nare $)$ of PBS. A comparative group of mice were immunised with $60 \mu \mathrm{g}$ of $\mathbf{1}$ dissolved in $30 \mu \mathrm{L}(15 \mu \mathrm{L} /$ nare $)$ of PBS. Prior to immunisation, mice were anaesthetized with a concoction of xylazine and ketamine (1:1:10 mixture of xylazine:ketamine: $\mathrm{H}_{2} \mathrm{O}$; Provet, Sydney, Australia).

For long-term immunological study, unvaccinated $(\mathrm{v}(-))$ and mice previously immunized with $\mathbf{L} \mathbf{1}$ were stimulated with $\mathbf{L 1}, 10 \mu \mathrm{L} /$ nare at day 186 post primary immunization.

\subsubsection{Collection of serum and saliva}

Serum was collected on days 20,41, 60, 200 post primary immunization to determine the level of J14-specific IgG antibodies. Blood $(10 \mu \mathrm{L})$ was collected via tail bleed into $90 \mu \mathrm{L}$ PBS. Serum was collected following centrifugation at $1400 \mathrm{~g}$ for $10 \mathrm{~min}$ and supernatant was kept at $-80^{\circ} \mathrm{C}$ before further analysis.

Saliva was collected on day 7, 28, 49 and 193 post primary immunization. Mice were given pilocarpine $(50 \mu \mathrm{L}$ of $0.1 \%$ pilocarpine) intraperitoneally (i.p.) and left for 10 min before collecting saliva. Collected saliva was added to $1 \mu \mathrm{L}$ of protease inhibitor, phenylmethanesulfonylfluoride (PMSF) solution and centrifuged at $1400 \mathrm{~g}$ for 10 min. Supernatant was kept at $-80^{\circ} \mathrm{C}$ before further analysis.

\subsubsection{Determination of antibody titres by ELISA}

An enzyme-linked immunosorbent assay (ELISA) was performed to measure J14specific serum IgG, including $\operatorname{IgG} 1$ and $\operatorname{IgG} 2 \mathrm{a}$ isotypes, and $\operatorname{Ig}$ A titres. A 1:100 concentration of serum to $0.5 \%$ skim milk/PBS-Tween 20 buffer was serially diluted 
1:2 down the plate. A 1:4 dilution of saliva extract (50 $\mu \mathrm{L}$ of extract into $150 \mu \mathrm{L}$ of skim milk/Tween 20 mixture) was titrated 1:2 down the plate. Optical density (OD) was read at a wavelength of $450 \mathrm{~nm}$ on the SpectraMax microplate reader. Antibody titres (IgG and $\operatorname{IgA}$ ) were defined as the lowest dilution with an optical density of more than three times the standard deviation, greater than the mean absorbance of control wells containing naïve mouse sera. IgG1 and IgG2a titres were derived from OD values (1:200) dilution, which were subtracted from naïve mice sera.

Statistical significance $(p<0.05)$ was determined using one-way ANOVA with Tukey post hoc test for determination of J14-specific IgG and IgA titres.

\section{Results}

\subsection{Synthesis and characterization}

Boc- and Fmoc- SPPS were applied for the synthesis of compounds 1-5. Resultant compounds were purified and incorporated into liposomes. Liposomes were formulated using cationic lipid (DDAB), DPPC and cholesterol by the lipid hydration method. Liposomes were characterized for size, surface charge and morphology using dynamic light scattering (DLS) and transmission electron microscopy (TEM) (Table

\section{1, Figure 2).}

Table 1. Physicochemical characterization of liposomal constructs.

\begin{tabular}{lllll}
\hline Liposomes & Size & Zeta potential & $\begin{array}{l}\text { Polydispersity } \\
\text { Index (PDI) }\end{array}$ & $\begin{array}{l}\text { Loading } \\
\text { Efficacy }\end{array}$ \\
\hline $\mathbf{L 1}$ & $180 \mathrm{~nm}$ & $+64 \mathrm{mV}$ & 0.2 & $65 \pm 12 \%$ \\
\hline $\mathbf{L 2}$ & $180 \mathrm{~nm}$ & $+54 \mathrm{mV}$ & 0.08 & $85 \pm 13 \%$ \\
\hline $\mathbf{L 3}$ & $170 \mathrm{~nm}$ & $+51 \mathrm{mV}$ & 0.07 & $92 \pm 8 \%$ \\
\hline $\mathbf{L 4}$ & $160 \mathrm{~nm}$ & $+57 \mathrm{mV}$ & 0.03 & $98 \pm 2 \%$ \\
\hline
\end{tabular}




\subsection{Cell uptake studies}

Dendritic cells and macrophages account for the majority of the antigen-presenting cells (APCs), which are responsible for initiating the adaptive immune responses. Liposomal uptake studies were evaluated using murine $\mathrm{CD} 11 \mathrm{c}^{+}$dendritic cells and F4/80 ${ }^{+}$macrophages. There was no significant difference in uptake of L1-L4 by dendritic cells and macrophages.

\subsection{Immunogenicity of liposomal vaccine candidates}

Female Swiss mice were intranasally immunized on day 0 with $20 \mu \mathrm{L}(10 \mu \mathrm{L} /$ nare $)$ of L1-L4 which contained $60 \mu \mathrm{g}$ of peptides or lipopeptides, followed by two booster doses on day 21 and day 42 (Figure 2). Mice receiving control were given $30 \mu \mathrm{L}$ (15 $\mu \mathrm{L} /$ nare) of mixture containing J14 (30 $\mu \mathrm{g})$, P25 (30 $\mu \mathrm{g})$ and CTB $10 \mu \mathrm{g}$ dissolved in $30 \mu \mathrm{L}$ of PBS. Mice immunized with PBS were given $30 \mu \mathrm{L}$ of PBS (15 $\mu \mathrm{L} /$ nare).

All tested formulations have induced significantly higher serum IgG titres compared to mice administered with PBS (Figure 4) after the third immunization (day 60). Mice administered with $\mathbf{L 4}$ showed significantly higher IgG titres when compared with the control, i.e. mice immunized with a mixture of peptides J14 and P25, and CTB adjuvant (Figure 4). The antibody titres induced by $\mathbf{L} \mathbf{4}$ were discernibly higher than those induced by the other three liposomal vaccine candidates (L1-L3), though the differences were not statistically significant $(p>0.05)$. Liposomes encapsulating epitopes conjugated with two lipids moieties (L3 and L4), elicited higher titres than liposomes that contained antigens with single lipid moiety (L2). Mice immunized with $\mathbf{L 4}$ elicited higher $\operatorname{IgG}$ titres compared to $\mathbf{1}$, however the difference was not statistically significant. 
Similar trends were observed in salivary IgA responses (Figure 5). Mice immunized with liposome formulations encapsulating lipopeptides with two lipid moieties (L3 and L4) showed higher IgA titres when compared with mice that received PBS. L4 induced higher IgA titres, compared to the positive controls containing CTB; however, the differences were not statistically significant. L2 induced weak J14specific IgA titres while titres of mice immunized with liposomal formulation L1 were comparable to those produced by mice treated with PBS.

The most potent liposomal vaccine candidate was analysed for antibody subtypes (IgG1 and IgG2a) using the pooled sera of immunized mice. IgG2a levels were significantly higher $(* * * *, p<0.0001)$ in mice immunized with $\mathbf{L} 4$ when compared with mice that received $\mathbf{1}$. No $\operatorname{IgG} 2$ a titres were detected in the adjuvanted control (Figure 7).

High levels of IgG were maintained in mice vaccinated with $\mathbf{L 4}$. Sera were collected from mice previously immunized with $\mathbf{L 4}$ and unimmunized mice [v(-)], five months post final immunization. Mice in both groups were then immunized with L4. Higher J14-specific IgG titres were observed in mice previously primed with L4 (Figure 7). These titres were statistically significantly higher when compared to mice immunized for the first time with $\mathbf{L 4}$ (Figure 7b). Interestingly, mice treated with L4 [v(-)+L4] for the first time, showed statistically significant immune responses.

Saliva was collected prior and after seven days following re-stimulation of both groups [v(-) and L4]. Significant differences in J14-specific IgA titres were observed before and after re-stimulating in mice that had already been primed with L4 (Figure 8). Mice which were not immunized previously $[\mathrm{v}(-)]$, showed significantly higher titres upon single immunization with L4. Mice restimulated with L4 elicited 
significantly higher J14-specific IgA titres in comparison to titres in mice which received only one immunization of $\mathbf{L 4}([\mathrm{v}(-)+\mathbf{L} \mathbf{4}])(* * * *, p<0.0001)$.

\section{Discussion}

Liposomes are widely used for drug and vaccine delivery, thanks to its invaluable properties of being biocompatible and biodegradable while concurrently increasing potency and reducing the toxicity of delivered agents [30]. Other advantages of using liposomes as a delivery system include its ability to entrap relatively large amounts of antigen while protecting the antigen from degradation. Liposomes composed of DPPC, DDAB and cholesterol, were formulated to encapsulate antigens with moderate to high encapsulation efficacy. The high encapsulation was observed for lipidated peptides due to their ability to anchor into the lipidic layer through their lipidic tails [31]. Size analysis by DLS and TEM (Figure 2) showed that LCP-loaded liposomes vaccines were approximately $200 \mathrm{~nm}$ in diameter. Nanoparticles between 20-200 nm have been known to easily travel to lymph nodes and be preferentially endocytosed by dendritic cells [32]. Other properties of liposomes (e.g. charge) were also reported to have an influence on their recognition by APCs [33]. However, the changes of entrapped antigens $(\mathrm{P} 25, \mathrm{~J} 14, \mathbf{1 - 5})$ did not affect uptake of liposomes by APCs as shown in Figure 3. This lack of differentiation can be explained by similar surface charges and size of the liposomes irrespective of entrapped antigens (L1-L4, Table 1) [34].

Systemic IgG antibodies are needed to prevent septicaemia in the circulatory system which leads to invasive GAS sequelae. However, a vaccine that is also able to produce mucosal IgA is beneficial in order to prevent colonization of GAS in the 
mucosa lining and to prevent entry of bacteria into the circulatory system [35]. Mice immunized with $\mathbf{L 4}$ gave the highest J14-specific systemic and mucosal antibody titres which were higher than those induced by mice immunized with peptide antigens adjuvanted with strong but toxic CTB adjuvant (control) (Figure 4 and 5). The use of liposomes contributed to a synergistic effect whereby vaccine candidates containing both liposomes and two lipids in their constructs (L3 and L4) evidently induced stronger immune responses than a) lipidated peptide (1) b) peptides encapsulated in liposomes (L1) or c) lipopeptides with a single lipid moiety encapsulated in liposomes (L2) (Figure 4). Importantly, this synergism was required to induce any significant IgA production (L3 and L4, Figure 5). Interestingly, it was reported that J14 peptide alone or with single lipid moiety did not generate any J14-specific antibody titres, [36] while herein upon encapsulation into liposomes, those compounds induced production of IgG in similar levels to those of the positive control.

In any vaccine development, unbalanced Th1/Th2 responses often lead to pathological immune reaction, causing enhanced disease symptoms or excessive inflammation. Therefore we assessed Th1/Th2 responses by means of IgG subtyping. Liposomes $\mathbf{L 4}$ induced a more balanced Th1/Th2 response, though skewed towards a Th2 response. Such balanced responses are favourable as the excess of $\mathrm{Th} 2$ responses (control group and construct 1) may counteract the microbicidal action of Th1 [37], which is not favourable in GAS infections.

Continuous presence of antibody titres following vaccination is needed to protect an individual from future GAS infections. Long-term antibody titres are mainly dependent on memory B cells and long-lived plasma cells which reside in the bone marrow. Long- lived plasma cells are able to continuously secrete antibody in the 
absence of antigen for more than a year [38]. This continuous antibody production is evident in mice treated with $\mathbf{L} \mathbf{4}$ where antibody titres drop only slightly after 185 days post primary immunization and are fully restored upon restimulation (Figure 8 and 9). It is noteworthy that IgA titres increased significantly upon restimulation with $\mathbf{L 4}$ (Figure 9). Interestingly, previously unimmunised mice [(v-)] elicited high $\operatorname{IgG}$ and IgA titres following the single immunization of $\mathbf{L 4}$, thereby demonstrating high immunostimulatory potency of the liposome/lipopeptide system. Such ability of single immunization to induce high antibody titres in aged mice has been never before reported for a GAS vaccine.

Overall, the highest antibody titres (IgA and $\operatorname{IgG}$ ) could be seen in mice vaccinated with L4 (Figure 4 and 5). Similar but slightly weaker responses were detected when mice were treated with liposomes bearing a mixture of lipopeptides $\mathbf{4}$ and $\mathbf{5}$, suggesting the importance of the conjugation of T-helper and B-cell epitope into one molecule. The use of liposomes most likely assisted the delivery of peptide epitope, $\mathrm{J} 14$ and P25 to the same cell, which is crucial, as J14 peptide alone is unlikely to induce strong antibody titres in an outbred population due to its small size. Moreover, incorporation of lipidated peptide into liposomes was able to induce $\operatorname{IgG}$ titres that were stronger than the positive control adjuvanted with CTB.

\section{Conclusion}

In this study, we have investigated the use of cationic liposomes together with lipopeptide antigens as vaccine candidates against GAS. The cationic liposomal formulation (L4) improved the immunogenicity of the lead vaccine candidate $\mathbf{1}$, inducing significantly higher $\operatorname{IgG}$ and $\operatorname{IgA}$ antibody titres. L4 was also able to induce 
more balanced and long lasting Th1/Th2 responses in mice which are usually favourable for vaccine performance. Thus the use of liposomes renders it a very promising and versatile tool which could be used for the delivery of other lipopeptide vaccines.

\section{References}

[1] J.R. Carapetis, A.C. Steer, E.K. Mulholland, M. Weber, The global burden of group A streptococcal diseases, Lancet Infect. Dis. 5 (2005) 685-694.

[2] G.S. Chhatwal, Host-pathogen interactions in streptococcal diseases, in: G.S. Chhatwal (Ed.), Host-Pathogen Interactions in Streptococcal Diseases, Springer, 2013.

[3] World Health Organization, The current evidence for the burden of group a streptococcal diseases. Discussion papers on child health. Department of child and adolescent health and development, 2005.

[4] A.P. Ralph, J.R. Carapetis, Group a streptococcal diseases and their global burden, in: G.S. Chhatwal (Ed.), Host-Pathogen Interactions in Streptococcal Diseases, 2013.

[5] T.L. Lamagni, J. Darenberg, B. Luca-Harari, T. Siljander, A. Efstratiou, B. HenriquesNormark, J. Vuopio-Varkila, A. Bouvet, R. Creti, K. Ekelund, M. Koliou, R.R. Reinert, A. Stathi, L. Strakova, V. Ungureanu, C. Schalen, A. Jasir, Epidemiology of severe Streptococcus pyogenes disease in Europe, J. Clin. Microbiol. 46 (2008) 23592367.

[6] J.N. Cole, T.C. Barnett, V. Nizet, M.J. Walker, Molecular insight into invasive group A streptococcal disease, Nat. Rev. Micro. 9 (2011) 724-736.

[7] B. Remenyi, J. Carapetis, R. Wyber, K. Taubert, B.M. Mayosi, Position statement of the World Heart Federation on the prevention and control of rheumatic heart disease, Nat. Rev. Cardiol. 10 (2013) 284-292.

[8] M.J. Walker, T.C. Barnett, J.D. McArthur, J.N. Cole, C.M. Gillen, A. Henningham, K.S. Sriprakash, M.L. Sanderson-Smith, V. Nizet, Disease manifestations and pathogenic mechanisms of group a Streptococcus, Clin. Microbiol. Rev. 27 (2014) 264-301.

[9] H.S. Courtney, D.L. Hasty, J.B. Dale, Molecular mechanisms of adhesion, colonization, and invasion of group A streptococci, Ann. Med. 34 (2002) 77-87.

[10] E. Medina, O. Goldmann, A.W. Toppel, G.S. Chhatwal, Survival of Streptococcus pyogenes within Host Phagocytic Cells: A Pathogenic Mechanism for Persistence and Systemic Invasion, J. Infect. Dis. 187 (2003) 597-603.

[11] M.W. Cunningham, Pathogenesis of group a streptococcal infections, CMR 13 (2000) 470-511.

[12] M.W. Cunningham, S.M. Antone, M. Smart, R. Liu, S. Kosanke, Molecular analysis of human cardiac myosin-cross-reactive B- and T-cell epitopes of the group A streptococcal M5 protein, Infect. Immun. 65 (1997) 3913-3923.

[13] B.F. Massell, L.H. Honikman, J. Amezcua, Rheumatic fever following streptococcal vaccination: Report of three cases, JAMA 207 (1969) 1115-1119.

[14] W.A. Hayman, E.R. Brandt, W.A. Relf, J. Cooper, A. Saul, M.F. Good, Mapping the minimal murine $\mathrm{T}$ cell and $\mathrm{B}$ cell epitopes within a peptide vaccine candidate from the conserved region of the M protein of group A streptococcus, Int. Immunol. 9 (1997) 1723-1733. 
[15] M.F. Good, M. Pandey, M.R. Batzloff, G.J. Tyrrell, Strategic development of the conserved region of the $\mathrm{M}$ protein and other candidates as vaccines to prevent infection with group A streptococci, Expert Rev. Vaccines 14 (2015) 1459-1470.

[16] M.R. Batzloff, W.A. Hayman, M.R. Davies, M. Zeng, S. Pruksakorn, E.R. Brandt, M.F. Good, Protection against group a streptococcus by immunization with j8-diphtheria toxoid: Contribution of j8- and diphtheria toxoid-specific antibodies to protection, J. Infect. Dis. 187 (2003) 1598-1608.

[17] C. Olive, M.-F. Ho, J. Dyer, D. Lincoln, N. Barozzi, I. Toth, M.F. Good, Immunization with a tetraepitopic lipid core peptide vaccine construct induces broadly protective immune responses against group a streptococcus, J. Infect. Dis. 193 (2006) 16661676.

[18] D. Bessen, V.A. Fischetti, Passive acquired mucosal immunity to group A streptococci by secretory immunoglobulin A, JEM 167 (1988) 1945-1950.

[19] A.A. Ahmad Fuaad, M.S. Pearson, D.A. Pickering, L. Becker, G. Zhao, A.C. Loukas, M. Skwarczynski, I. Toth, Lipopeptide Nanoparticles: Development of Vaccines against Hookworm Parasite, ChemMedChem 10 (2015) 1647-1654.

[20] A.M. Dougall, M. Skwarczynski, M. Khoshnejad, S. Chandrudu, N.L. Daly, I. Toth, A. Loukas, Lipid core peptide targeting the cathepsin D hemoglobinase of Schistosoma mansoni as a component of a schistosomiasis vaccine, Hum. Vaccin. Immunother. 10 (2014) 399-409.

[21] S.H. Apte, P.L. Groves, M. Skwarczynski, Y. Fujita, C. Chang, I. Toth, D.L. Doolan, Vaccination with lipid core peptides fails to induce epitope-specific $\mathrm{T}$ cell responses but confers non-specific protective immunity in a malaria model, PLoS One 7 (2012) e40928.

[22] A.A. Ahmad Fuaad, R. Roubille, M.S. Pearson, D.A. Pickering, A.C. Loukas, M. Skwarczynski, I. Toth, The use of a conformational cathepsin D-derived epitope for vaccine development against Schistosoma mansoni, Bioorg. Med. Chem. 23 (2015) 1307-1312.

[23] P.M. Moyle, C. Olive, M.-F. Ho, M. Pandey, J. Dyer, A. Suhrbier, Y. Fujita, I. Toth, Toward the development of prophylactic and therapeutic human papillomavirus type16 lipopeptide vaccines, J. Med. Chem. 50 (2007) 4721-4727.

[24] M. Zaman, A.-B.M. Abdel-Aal, Y. Fujita, Z.M. Ziora, M.R. Batzloff, M.F. Good, I. Toth, Structure-activity relationship for the development of a self-adjuvanting mucosally active lipopeptide vaccine against Streptococcus pyogenes, J. Med. Chem. 55 (2012) 8515-8523.

[25] M. Zaman, S. Chandrudu, A.K. Giddam, J. Reiman, M. Skwarczynski, V. McPhun, P.M. Moyle, M.R. Batzloff, M.F. Good, I. Toth, Group A Streptococcal vaccine candidate: contribution of epitope to size, antigen presenting cell interaction and immunogenicity, Nanomedicine (Lond) 9 (2014) 2613-2624.

[26] A.B. Abdel-Aal, M.R. Batzloff, Y. Fujita, N. Barozzi, A. Faria, P. Simerska, P.M. Moyle, M.F. Good, I. Toth, Structure-activity relationship of a series of synthetic lipopeptide self-adjuvanting group a streptococcal vaccine candidates, J. Med. Chem. 51 (2008) 167-172.

[27] M. Zaman, A.B. Abdel-Aal, K.S. Phillipps, Y. Fujita, M.F. Good, I. Toth, Structureactivity relationship of lipopeptide Group A streptococcus (GAS) vaccine candidates on toll-like receptor 2, Vaccine 28 (2010) 2243-2248.

[28] M. Skwarczynski, I. Toth, Lipid-core-peptide system for self-adjuvanting synthetic vaccine delivery, in: S.S. Mark (Ed.), Bioconjugation Protocols, Humana Press, 2011, pp. 297-308.

[29] A.D. Bangham, Properties and uses of lipid vesicles: An overview, Ann. N. Y. Acad. Sci 308 (1978) 2-7.

[30] V.P. Torchilin, Recent advances with liposomes as pharmaceutical carriers, Nat. Rev. Drug Discov. 4 (2005) 145-160. 
[31] S. Espuelas, A. Roth, C. Thumann, B. Frisch, F. Schuber, Effect of synthetic lipopeptides formulated in liposomes on the maturation of human dendritic cells, Mol. Immunol. 42 (2005) 721-729.

[32] M. Skwarczynski, I. Toth, Recent advances in peptide-based subunit nanovaccines, Nanomedicine (Lond) 9 (2014) 2657-2669.

[33] K.A. Ghaffar, A.K. Giddam, M. Zaman, M. Skwarczynski, I. Toth, Liposomes as nanovaccine delivery systems, Curr. Top. Med. Chem. 14 (2014) 1194-1208.

[34] C. Foged, C. Arigita, A. Sundblad, W. Jiskoot, G. Storm, S. Frokjaer, Interaction of dendritic cells with antigen-containing liposomes: effect of bilayer composition, Vaccine 22 (2004) 1903-1913.

[35] M. Pandey, S. Sekuloski, M.R. Batzloff, Novel strategies for controlling Streptococcus pyogenes infection and associated diseases: from potential peptide vaccines to antibody immunotherapy, Immunol. Cell Biol. 87 (2009) 391-399.

[36] F. Azmi, A.A. Ahmad Fuaad, A.K. Giddam, M.R. Batzloff, M.F. Good, M. Skwarczynski, I. Toth, Self-adjuvanting vaccine against group A streptococcus: application of fibrillized peptide and immunostimulatory lipid as adjuvant, Bioorg. Med. Chem. 22 (2014) 6401-6408.

[37] A. Berger, Th1 and Th2 responses: what are they?, BMJ 321 (2000) 424-424.

[38] R.A. Manz, A. Thiel, A. Radbruch, Lifetime of plasma cells in the bone marrow, Nature 388 (1997) 133-134. 


\section{Figures}

Figure 1. Schematic representation of a) peptide (P25 and J14) and lipopeptide constructs (1-5) b) encapsulated into liposomes (L1-L4).

Figure 2. Immunization schedule with marked immunization, saliva and serum collection points in days.

Figure 3. TEM image of liposomes (L4) encapsulating lipopeptide 1.

Figure 4. Uptake of liposomes by mice splenocyte-derived DCs and macrophages. Dextran-FITC was used as a positive control. The experiments were performed in triplicate and data presented as cells double positive for liposomes (labelled with DiI) and CD11c (A660) or F4/80 (APC-Cy7). a) CD11c (A660) was marker characteristic of dendritic cells and b) F4/80 (APC-Cy7) characteristic of macrophages. Error bars represent the mean \pm standard deviation of the three experiments.

Figure 5. J14-specific serum $\operatorname{IgG}$ titres $(\log 10)$ at day 60 post primary immunization for each individual mouse. Horizontal bar represents the mean of each group. Statistical analysis was performed using one-way ANOVA followed by Tukey's post hoc multiple comparison test $\left(^{*}, p<0.05 ; * *, p<0.01\right.$; ***, $p<0.001$; ****, $p<$ 0.0001). Statistical analysis was performed for mice immunized with peptide antigens in comparison to PBS treated mice.

Figure 6. J14-specific saliva IgA titres $(\log 2)$ at day 49 post primary immunization. Horizontal bar represents the mean of each group. Statistical analysis was performed using one-way ANOVA followed by Tukey's post hoc multiple comparison test (ns, $p$ $>0.05 ; *, p<0.05)$. All statistical analyses were performed for mice immunized with peptide antigens in comparison to PBS treated mice. 
Figure 7. J14-specific serum $\mathrm{IgG}$ isotype titres (OD 450) at day 60 post primary immunization. Error bars represent standard deviation.

Figure 8. J14-specific serum IgG titres $(\log 10)$ before and after restimulation with L4. Mean J14-specific IgG antibody titres for each group are represented as the bar. Statistical analysis was performed using two-way ANOVA followed by Tukey's post hoc multiple comparison test (ns, $p>0.05$;,$p<0.05$; ***, $p<0.001$ ). a) J14specific serum IgG titres at day 186 post primary immunization, where $\mathrm{v}(-)$ are unimmunized mice (PBS group). b) J14-specific serum IgG titres 200 days, 14 days after restimulation with $\mathbf{L} 4$.

Figure 9. J14-specific salivary IgA titres $(\log 2)$. Mean J14-specific IgA antibody titres for each group are represented as the bar. Statistical analysis was performed using two-way ANOVA followed by Tukey's post hoc multiple comparison test ${ }^{*}, p$ $<0.05$; **, $p<0.01$; ***, $p<0.001$; ****, $p<0.0001)$. a) J14-specific serum IgA titres at day 186 post primary immunization. b) J14-specific serum IgA titres post primary immunization with $\mathbf{L 4}$ at day 193 where v(-) are unimmunized mice (PBS group). 
a)

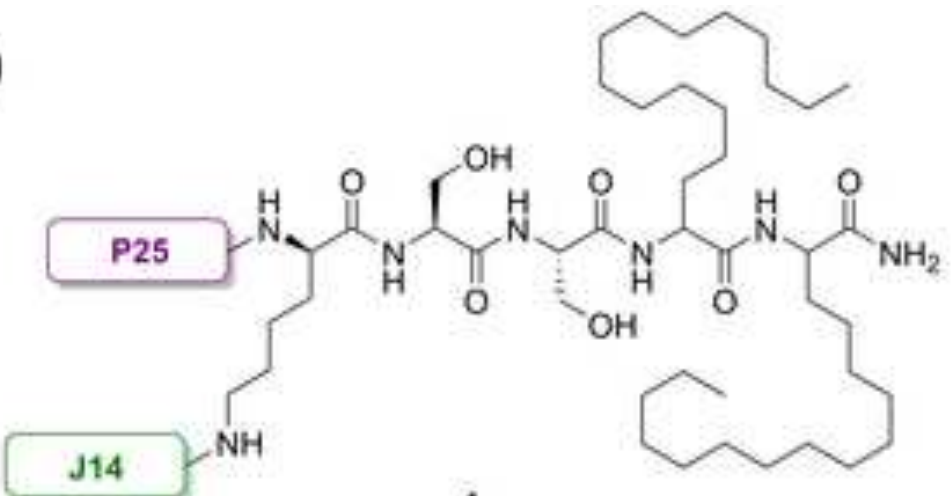

1

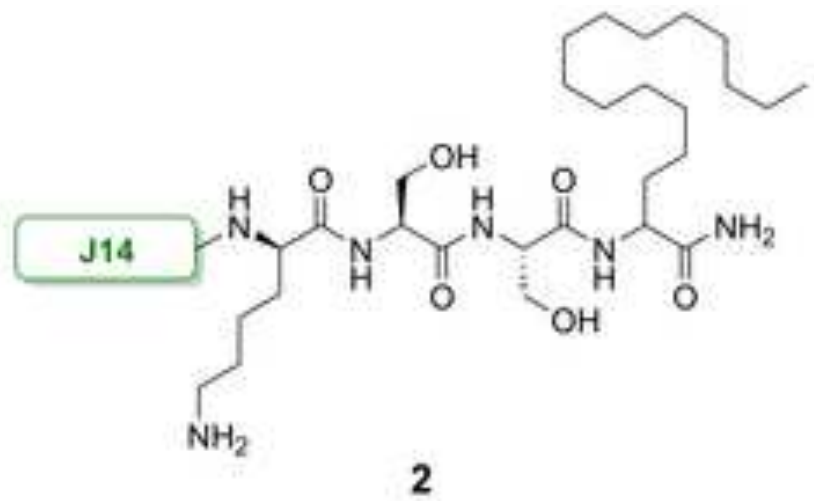

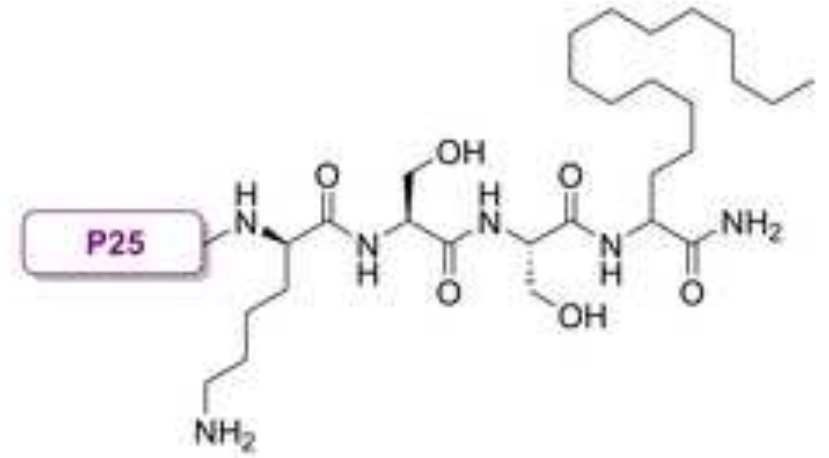

3

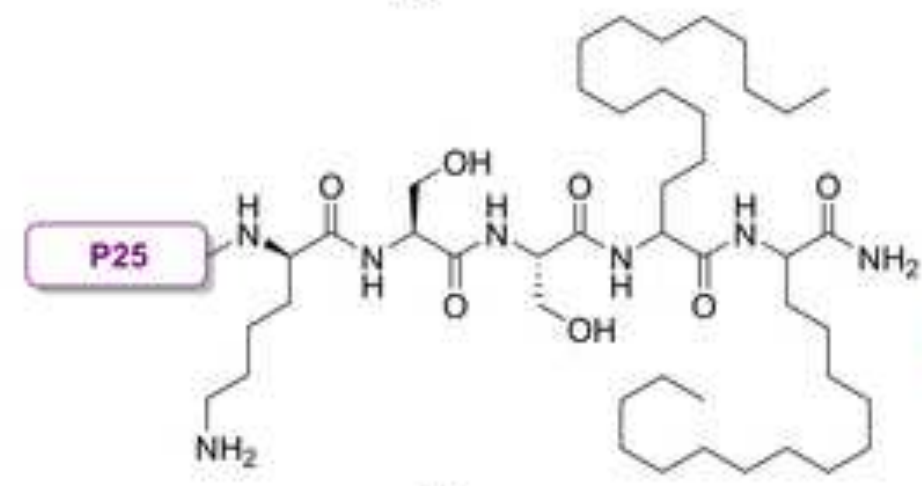

5

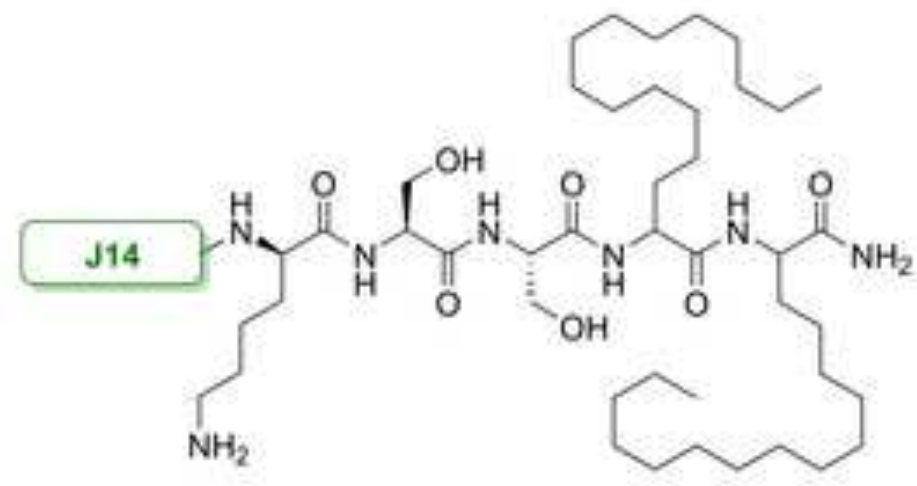

4

$J 14=$ KQAEDKVKASREAKKQVEKALEQLEDKVK P25 = KLIPNASLIENCTKAEL

b)

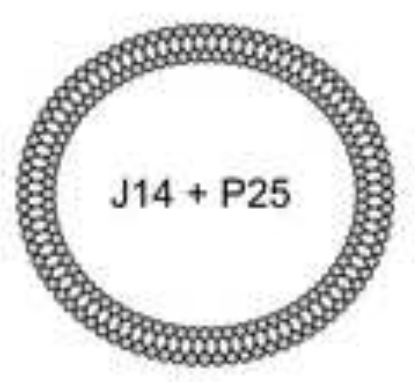

L1

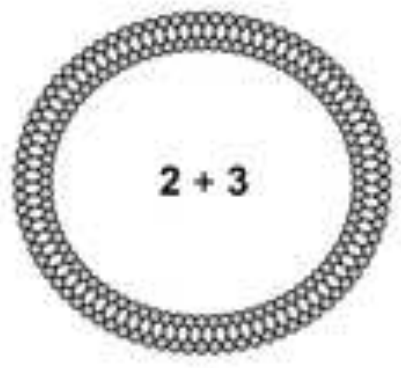

L2

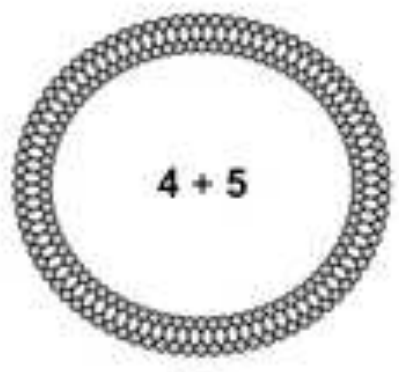

L3

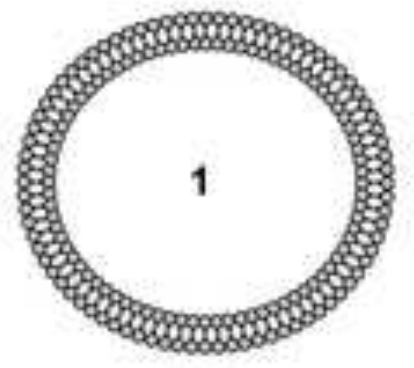

L4 


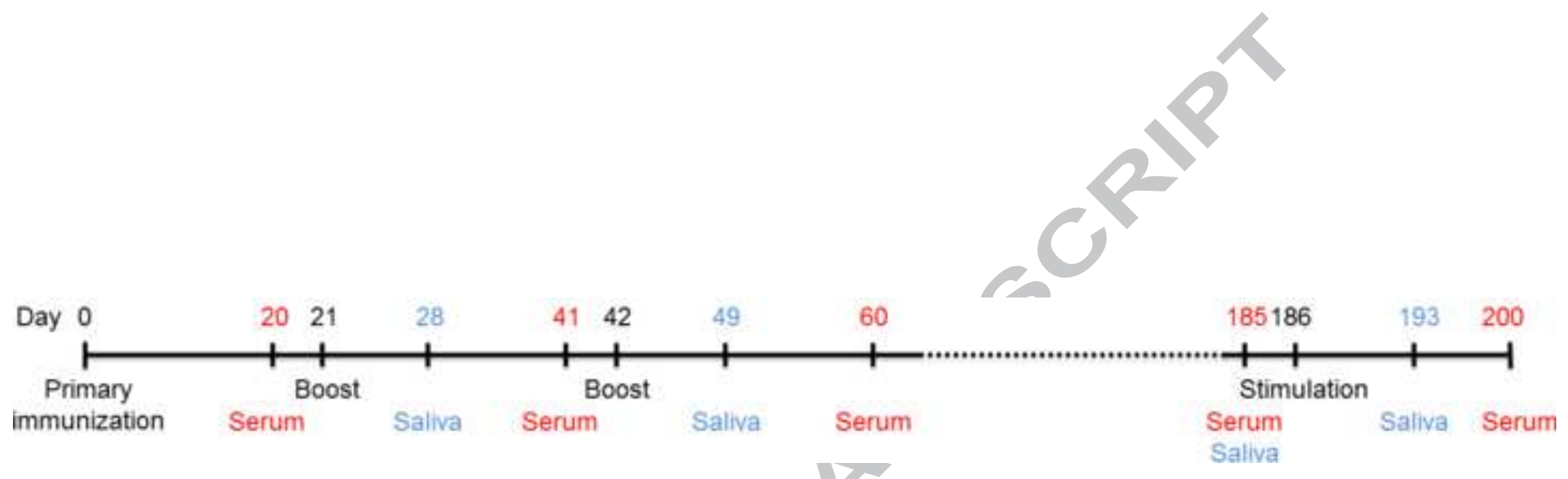




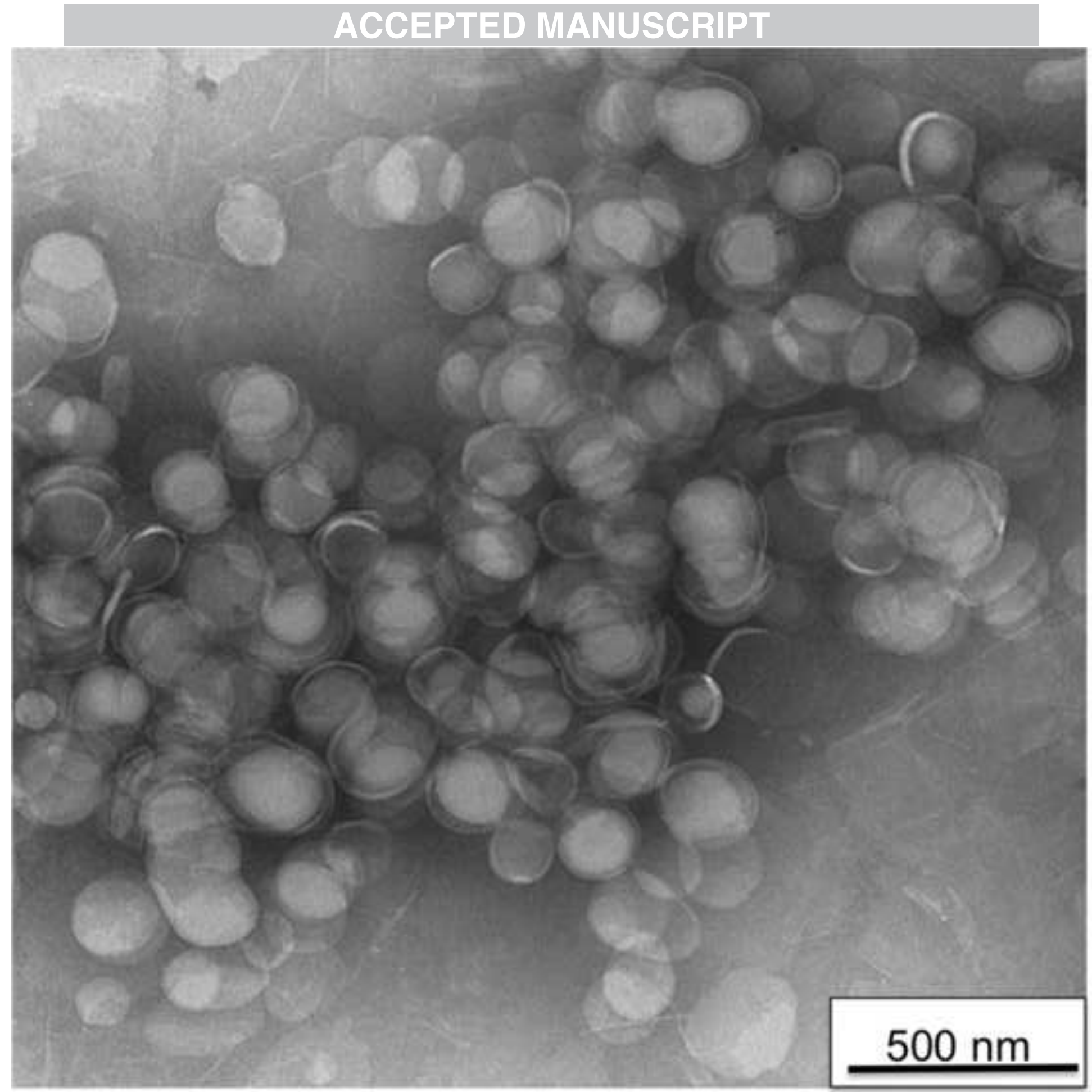

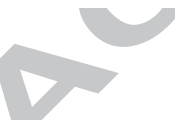



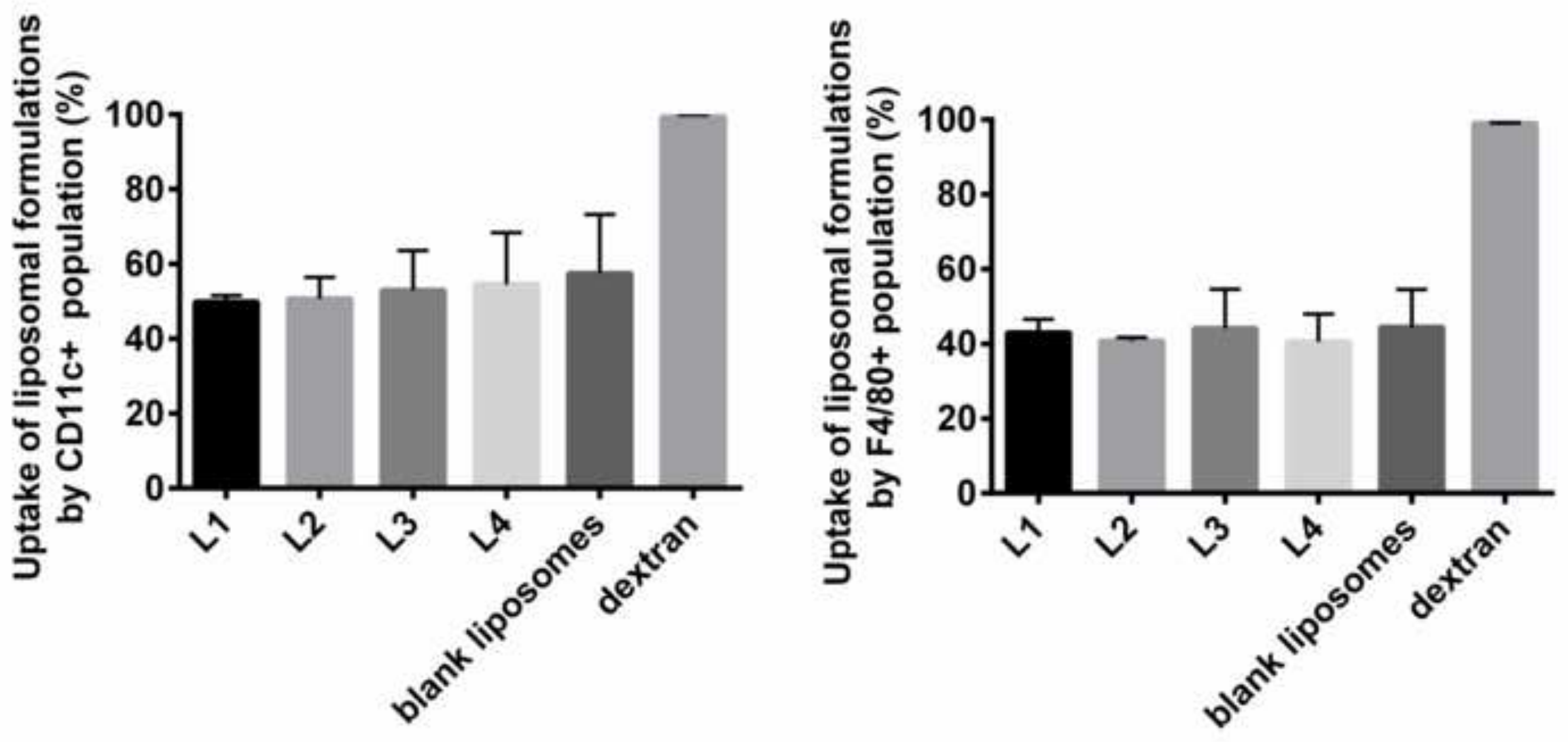
*
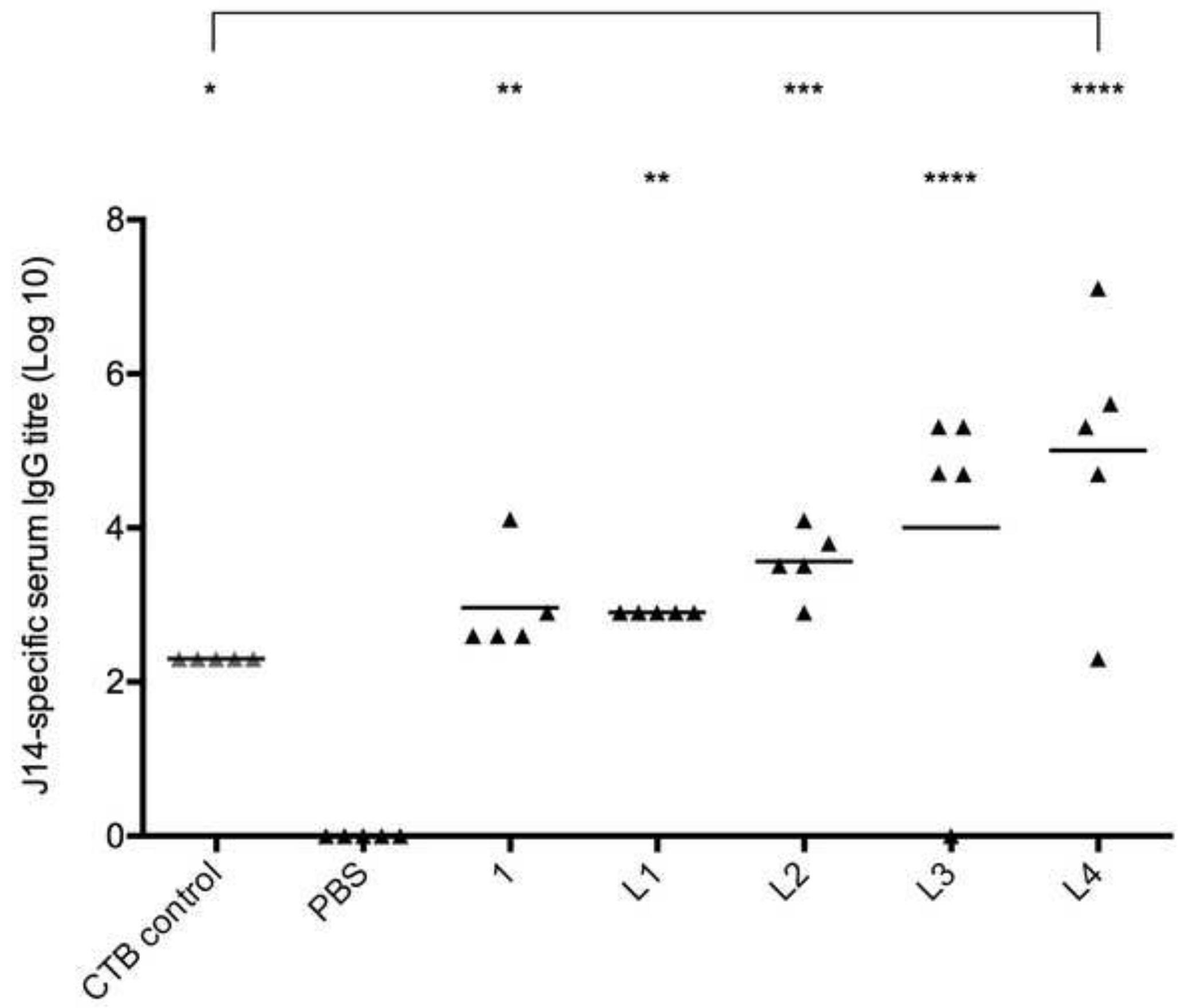


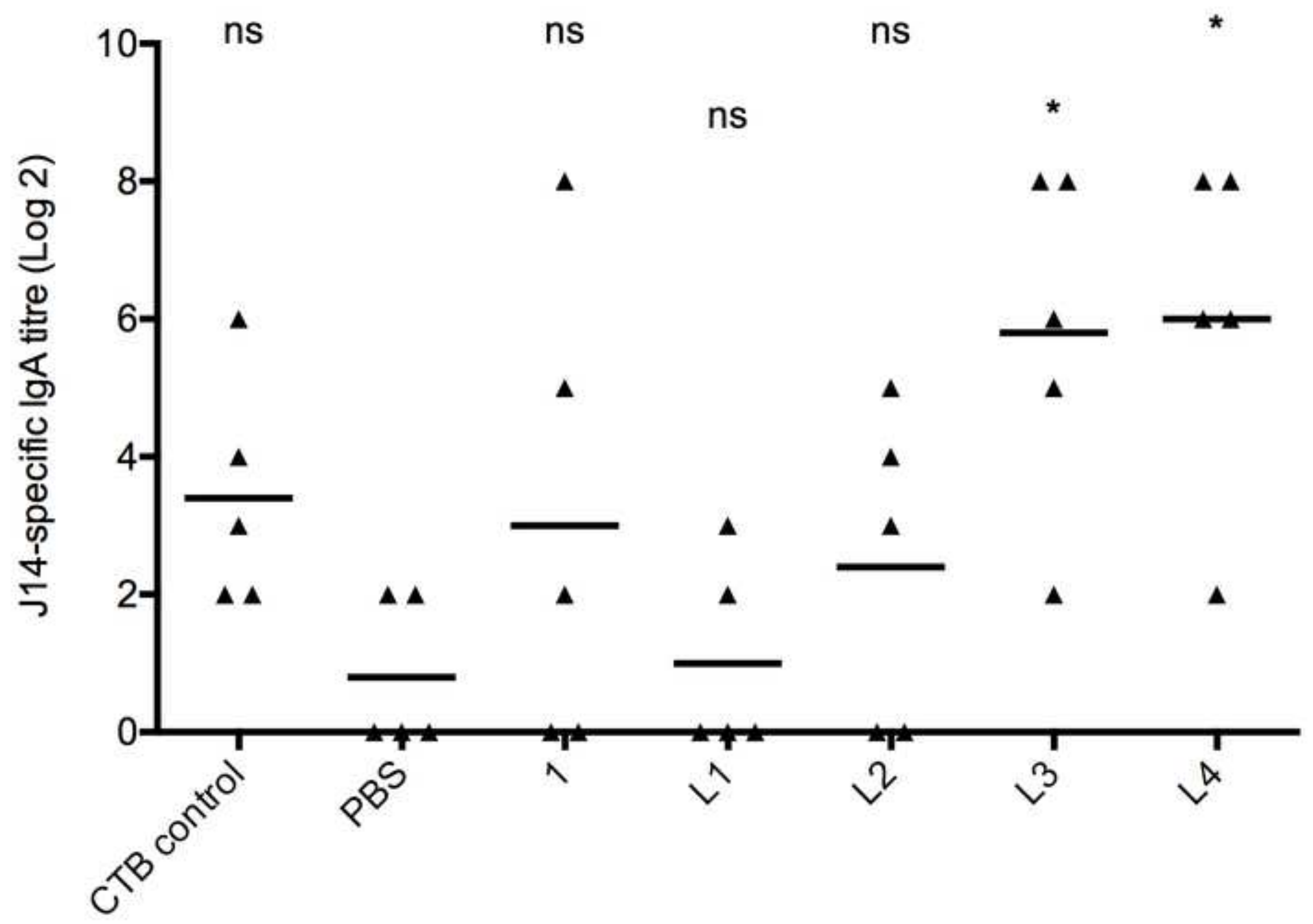




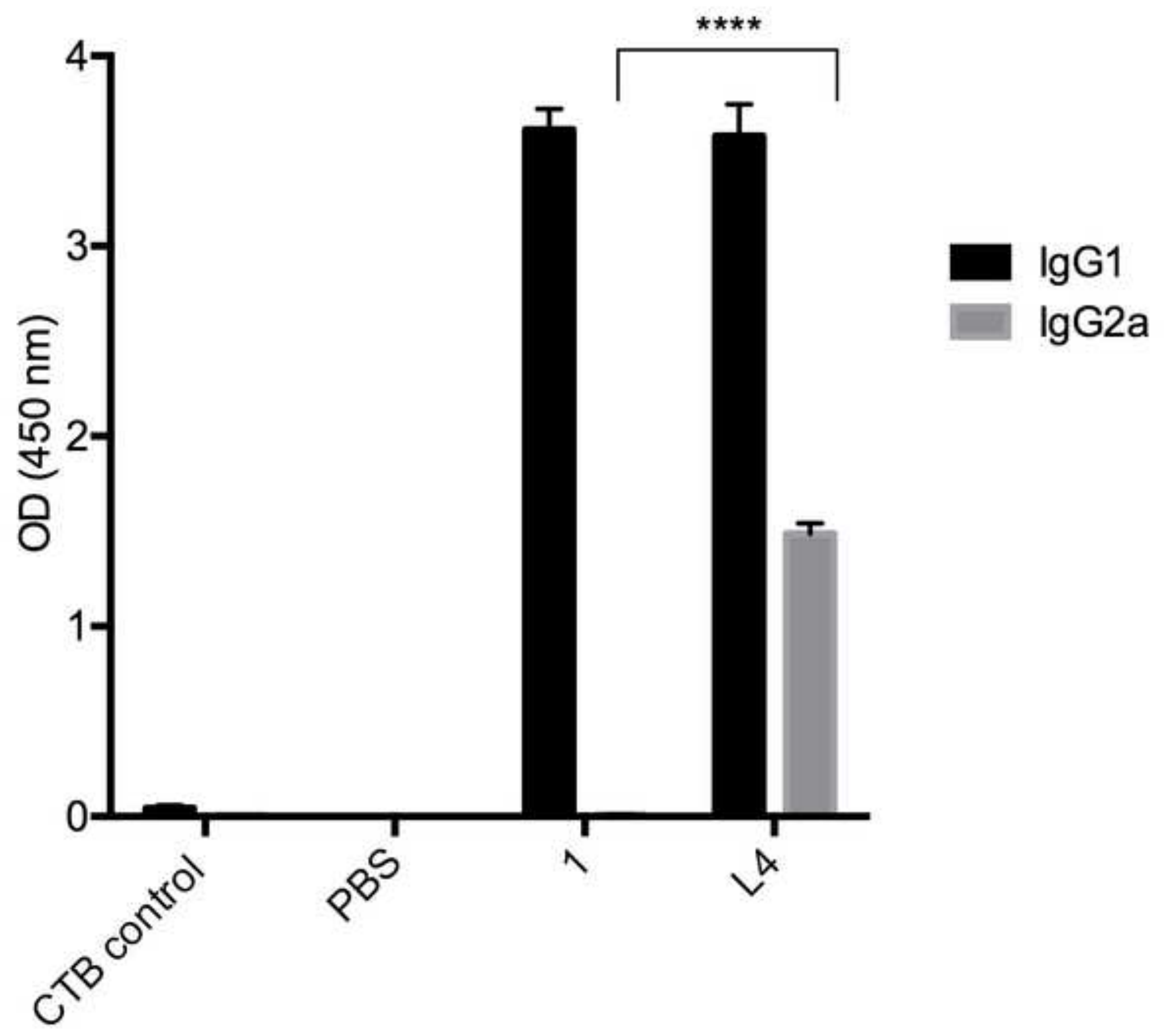


ns

a)

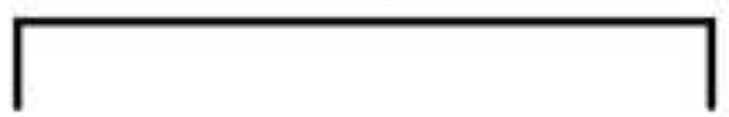

**

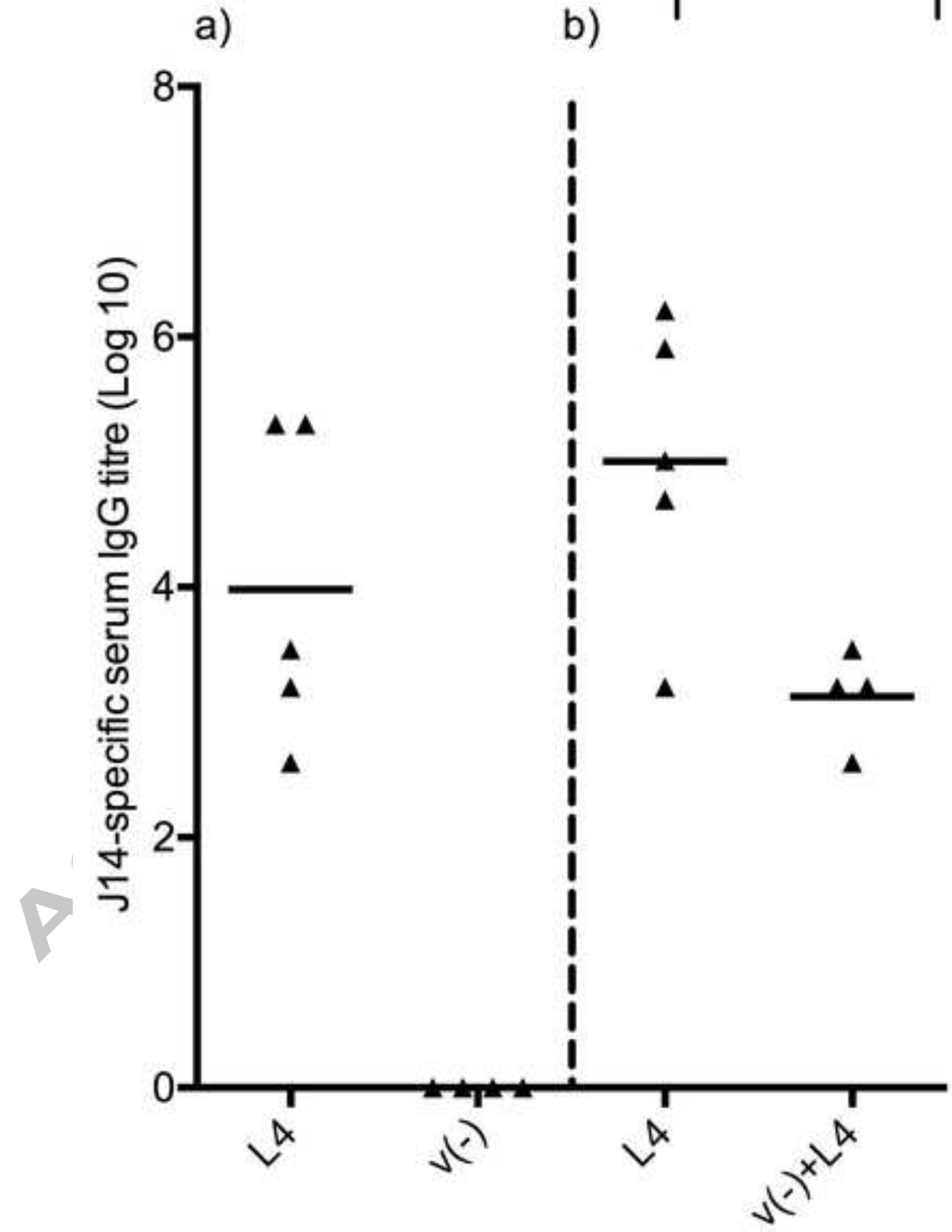

b)

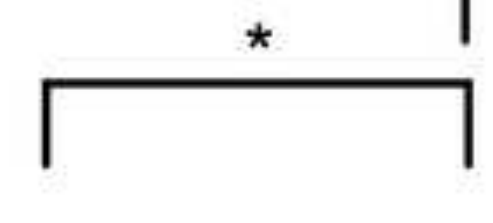


***

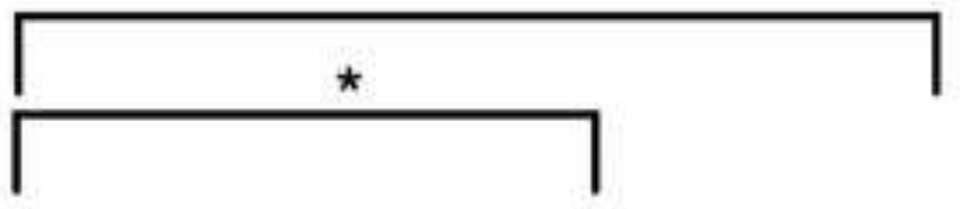

**

a)
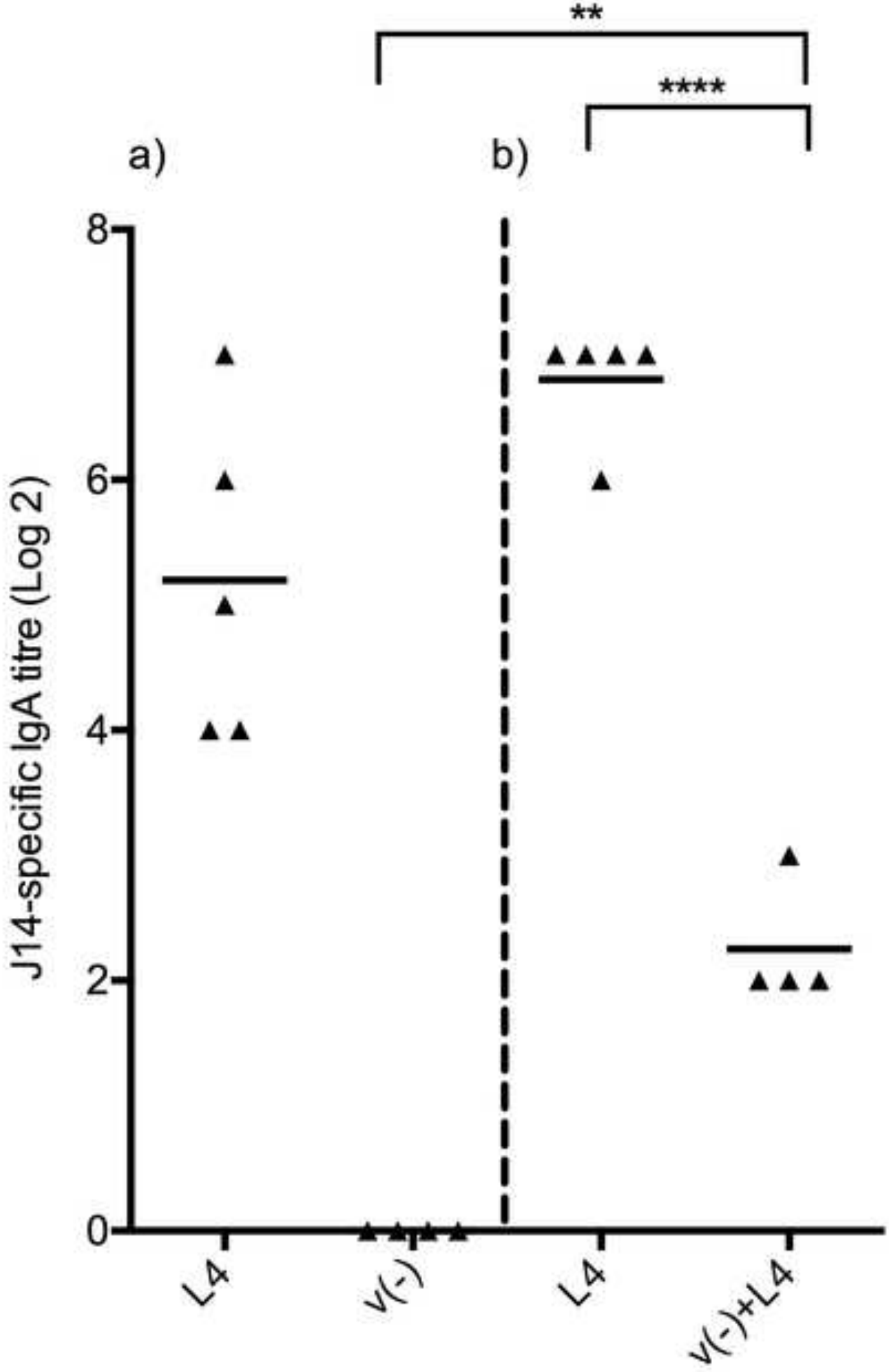


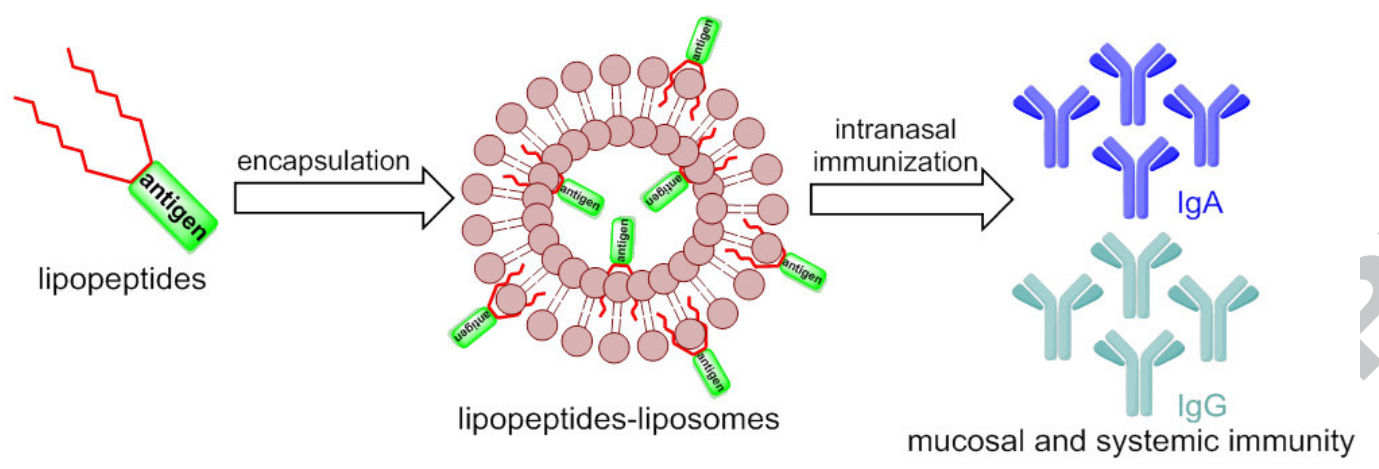


Statement of Significance:

Group A Streptococcus, causing rheumatic heart diseases, kills approximately half a million people annually. There is no vaccine available against the infection. Mucosal immunity is vital in ensuring an individual is protected as this gram positive bacteria initially colonizes at the throat. Herein, we demonstrated that lipopeptides entrapped by liposomes induced both mucosal and systemic immunity. High levels of antibody (IgA and $\mathrm{IgG}$ ) titres were detected even five months post immunization and lead vaccine candidate was able to induce humoral immune responses even after single immunization. Thus, the combination of lipopeptides and liposomes generates a very promising delivery system for intranasal vaccines. 


\section{Accepted Manuscript}

Liposome-based Intranasal Delivery of Lipopeptide Vaccine Candidates Against Group A Streptococcus

Khairunnisa Abdul Ghaffar, Nirmal Marasini, Ashwini Kumar Giddam, Michael Batzloff, Michael Good, Mariusz Skwarczynski, Istvan Toth

PII:

S1742-7061(16)30165-9

DOI: http://dx.doi.org/10.1016/j.actbio.2016.04.012

Reference: ACTBIO 4197

To appear in:

Acta Biomaterialia

Received Date:

14 December 2015

Revised Date:

25 February 2016

Accepted Date:

7 April 2016

Please cite this article as: Ghaffar, K.A., Marasini, N., Giddam, A.K., Batzloff, M., Good, M., Skwarczynski, M., Toth, I., Liposome-based Intranasal Delivery of Lipopeptide Vaccine Candidates Against Group A Streptococcus, Acta Biomaterialia (2016), doi: http://dx.doi.org/10.1016/j.actbio.2016.04.012

This is a PDF file of an unedited manuscript that has been accepted for publication. As a service to our customers we are providing this early version of the manuscript. The manuscript will undergo copyediting, typesetting, and review of the resulting proof before it is published in its final form. Please note that during the production process errors may be discovered which could affect the content, and all legal disclaimers that apply to the journal pertain. 